\title{
СТРУКТУРА АДМІНІСТРАТИВНОЇ ВІДПОВІДАЛЬНОСТІ ЗА ПРАВОПОРУШЕННЯ У СФЕРІ ЗАХИСТУ КОНКУРЕНЦІЇ
}

\begin{abstract}
Анотація. Стаття присвячена дослідженню структури адміністративної відповідальності за правопорушення у сфері захисту конкуренції. Адміністративна відповідальність за правопорушення у сфері захисту конкуренції це вид адміністративної відповідальності, застосовуваний судовими або несудовими органами при встановленні складу адміністративного правопорушення в формі монополістичної діяльності або недобросовісної конкуренції і безпосередньо або побічно заподіюе шкоду правам і законним інтересам конкурента, споживачам і конкуренції, що знаходить вираз у застосуванні адміністративних покарань. Проаналізовано підстави застосування адміністративної відповідальності у сфері захисту конкуренції. Визначено мету адміністративної відповідальності у сффері захисту конкуренції. Розкрито підстави адміністративної відповідальності у зазначеній сфері. Охарактеризовано об’єктивні і суб’єктивні ознаки даних правопорушень. Встановлено, що об’єктом даного правопорушення е суспільні відносини, які складаються у сфері економічних відносин і покликані забезпечувати свободу здійснення підприемницької діяльності в умовах добросовісної конкуренції на ринку. Визначено, що об’єктивна сторона правопорушення - це зовнішній прояв протиправного діяння, до ознак якого відносять суспільно-небезпечний наслідок і причинний зв'язок. Суб์'єкт даного правопорушення спеціальний. Досліджено суб'єктивну сторону адміністративних правопорушень у сфері захисту конкуренції, що характеризуе ставлення суб'екта правопорушення до вчинюваного ним діяння, у даному виді правопорушення форма вини (умисел чи необережність) не впливае на юридичну відповідальність. Встановлено, що мета адміністративної відповідальності у сфері захисту економічної конкуренції полягае в попередженні негативних проявів у сфері господарювання.
\end{abstract}

Ключові слова: адміністративна відповідальність, правопорушення, конкуренція, захист конкуренції, структура правопорушення.

Yarema Oksana

Lviv State University of Internal Affairs

\section{THE COMPOSITION OF THE ADMINISTRATIVE RESPONSIBILITY FOR OFFENSES IN THE FIELD OF COMPETITION PROTECTION}

Summary. The article is devoted to the study of the structure of administrative liability for offenses in the field of competition protection. Administrative liability for competition offenses is a type of administrative liability used by judicial or non-judicial bodies in determining the composition of an administrative offense in the form of monopolistic activity or unfair competition and directly or indirectly harms the rights and legitimate interests of competitors, consumers and competition. Application of administrative penalties. The grounds for the application of administrative liability in the field of competition protection are analyzed. The purpose of administrative responsibility in the field of competition protection is determined. The bases of administrative responsibility in the specified sphere are opened. The objective and subjective signs of these offenses are described. It is established that the object of this offense is public relations, which are formed in the field of economic relations and are designed to ensure the freedom of entrepreneurial activity in conditions of fair competition in the market. It is determined that the objective side of the offense is the external manifestation of the illegal act, the signs of which include socially dangerous consequences and causation. The subject of this offense is special. The subjective side of administrative offenses in the field of competition protection, which characterizes the attitude of the subject of the offense to the act committed by him, in this type of offense, the form of guilt (intent or negligence) does not affect legal liability. It is established that the purpose of administrative liability in the field of protection of economic competition is to prevent such negative manifestations in the field of management. Also determined that the specifics of consideration of cases of offenses in the area under investigation are separate proceedings. These are proceedings in cases of violation of antimonopoly law. It is determined that it is necessary to improve the legislation to increase the list of grounds for initiating cases on administrative offenses by the antimonopoly authorities.

Keywords: administrative responsibility, offense, competition, protection of competition, structure of offense.

$\Pi^{2}$ остановка проблеми. Адміністративна відповідальність займає особливе місце у числі заходів адміністративного примусу, що застосовуються у серері захисту конкуренції. Це пояснюеться двома обставинами: 3 одного боку, велика система складів адміністративних правопорушень і відповідних заходів адміністративного покарання, а з іншого - сильний вплив на правопорушника, у тому числі майнового характеру, що знаходить вираз у підвищеному розмірі адміністративного штрафу. Особлива роль адміністративної відповідальності як різновиду заходів адміністративного примусу обумовлена фрункцією стримуючої сили державного апарату, спрямованої проти зловживання свободою економічної діяльності.

Аналіз дослідження проблеми. Дослідження проблеми адміністративної відповідальності за правопорушення, у тому числі у сфрері захисту конкуренції, відображені у працях таких вчених-правознавців, як В. Б. Авер'янова, О. Ф. Андрійко, В. М. Бевзенка, А. І. Берлача, 
Ю. П. Битяка, О. П. Віхрова, П. В. Діхтіевського, I. С. Гриценка, Є. В. Додіна, Р. А. Калюжного, С. В. Ківалова, А. А. Козловського, М. І. Козюбри, Т. О. Коломоєць, В. К. Колпакова, О. В. Кузьменко, В. І. Курила, Є. В. Курінного, Р. С. Мельника, Н. М. Оніщенко, О. І. Остапенка, М. М. Тищенка, О. І. Харитонової, Ю. С. Шемчушенка та інших. Реалізація Угоди про асоціацію України і Європейського Союзу передбачає реформування національного антимонопольного законодавства. 3 цієї причини відповідальність потребуе своєчасної адаптації нормативної бази до постійно змінних економічних умов і науково опрацьованого системного підходу до регулювання даного інституту у сфері захисту конкуренції.

Мета статті: дослідження структури адміністративної відповідальності за правопорушення у сфері захисту конкуренції.

Виклад основного матеріалу. Адміністративна відповідальність у сфері захисту конкуренції заснована на відповідній компетенції антимонопольного органу, встановленої КУпАП, однак повністю з нею не збігається, а виходить за означені межі, про що говорить аналіз складів адміністративних правопорушень, виділених на основі приналежності до даній сфері суспільних відносин.

Сфера захисту конкуренції охоплюе ряд підгруп громадських відносин, що вимагае потреби регулювання значною кількістю правових норм, оскільки чинне законодавство містить охоронні норми у сфері захисту конкуренції у цивільному, кримінальному, адміністративному праві.

Значиму роль у правовому регулюванні сырери захисту конкуренщії відіграє адміністративне законодавство. Це значення заходів адміністративної відповідальності в структурі заходів адміністративного примусу, та місце Антимонопольного комітету України в структурі органів виконавчої влади, численність справ у сфрері захисту конкуренції, що розглядаються антимонопольним органом у позасудовому порядку.

Можна виділити наступні характерні ознаки даного виду юридичної відповідальності, зокрема: вона $е$ різновидом юридичної відповідальності та різновидом заходів адміністративного примусу, зберігаючи відмінні риси даних явищ; застосовуеться компетентним органом (посадовою особою); знаходить вираз у застосуванні адміністративних покарань, установлених КУпАП.

Для розуміння сутності адміністративної відповідальності, необхідної для виявлення ознак у сфері захисту конкуренції, слід звернутися до структури адміністративної відповідальності як інституту адміністративного права.

На основі наукового аналізу думок фахівців у галузі адміністративного права, пропонуемо визначити структурні елементи адміністративної відповідальності наступним чином: підстави адміністративної відповідальності (юридична, фрактична, процесуальна); умови залучення до адміністративної відповідальності; адміністративне стягнення; процедура застосування адміністративної відповідальності (провадження) [1, с. 427].

Як юридична підстава адміністративної відповідальності у сфері захисту конкуренції виступае КУпАП, що містить перелік адміністративних правопорушень і відсилае до положень
Закону «Про захист економічної конкуренції, а також до норм Закону «Про захист прав споживачів» $[2 ; 3 ; 4]$.

Згідно з положеннями КУпАП, на основі виділення специфічного об'єкта посягання можна виділити наступні склади правопорушень: недобросовісна конкуренція (ст. 164-3), порушення законодавства про закупівлі (ст. 164-14), зловживання монопольним становищем на ринку (ст.166-1), неправомірні угоди між підприемцями (166-2), дискримінація підприемщів органами влади і управління (ст. 166-3), порушення порядку подання інформації та виконання рішень Антимонопольного комітету України та його територіальних відділень (ст. 166-4), примушування до антиконкурентних узгоджених дій (ст. 166-18).

Фактичною підставою є адміністративне правопорушення. Адміністративним правопорушенням визнаеться протиправна, винна дія (бездіяльність) фрізичної або посадової особи, за яке КУпАП про адміністративні правопорушення встановлена адміністративна відповідальність.

Адміністративні правопорушення у сфері захисту конкуренції характеризуються такими рисами, як спрямованість посягання на права господарюючих суб'єктів, споживачів і законне конкурентне середовище, форма діяння у вигляді недобросовісної конкуренції або монополістичної діяльності.

Фактична підстава у вигляді адміністративного правопорушення має внутрішню структуру сукупність необхідних об'єктивних і суб'єктивних елементів, наявності яких досить для того, щоб говорити, що фактично є правопорушення. Дана сукупність іменуеться складом адміністративного правопорушення. Кваліфікація складу правопорушення дозволяе встановити наявність ознак протиправного діяння або їх відсутність. У разі відсутності ознак діяння, провадження у справі про адміністративне правопорушення не може бути розпочато, а розпочате підлягае закриттю.

В якості даних структурних компонентів, що утворюють склад адміністративного правопорушення, традиційно виділяються об'єкт, об'єктивна сторона, суб'єкт і суб'єктивна сторона правопорушення. Об'єктом адміністративного правопорушення виступають суспільні відносини, на які посягае правопорушення. Найбільш широкою групою таких відносин $е$ загальний об'єкт правопорушення. У сфері захисту конкуренції таким об'єктом виступають економічні права та законні інтереси фрізичних і юридичних осіб, суспільства та держави.

Родовий об'єкт це більш вузька група суспільних відносин, що збігаеться 3 найменуванням глави Особливої частини КУпАП - наприклад, у сфері захисту конкуренції склади адміністративних правопорушень зосереджені в Главі 12 Адміністративні правопорушення в галузі торгівлі, громадського харчування, сфері послуг, в галузі фрінансів і підприемницькій діяльності.

Видовий об'ект адміністративного правопорушення становить найбільш вузьку групу правопорушень, що посягають на окремі складові родового об'єкта. Безпосередній об'єкт є індивідуальним для кожного окремого складу.

Наприклад, ст. 164-3 КУпАП, що встановлюе адміністративну відповідальність за недобро- 
совісну конкуренцію, регулюе відносини у сореpi підприемницької діяльності, однак безпосереднім об'єктом правопорушення виступають конкретні суспільні відносини, які складаються в зв'язку з конкуренцією між господарюючими суб'ектами як необхідною умовою забезпечення свободи економічної діяльності.

В якості безпосереднього об'єкта правопорушення в представленому випадку виступають, в залежності від форми недобросовісної конкуренції, права господарюючого суб'єкта-конкурента. Різноманіття форм правопорушень у сфрері захисту конкуренції, так само як і недобросовісної конкуренції зокрема, є причиною значного числа варіацій змісту безпосереднього об'єкта адміністративного правопорушення. Недобросовісна конкуренція завдає шкоди стану конкуренції на ринку, конкурентам і споживачам.

Суб'єкти адміністративної відповідальності у сфрері захисту конкуренції представлені фрізичними і посадовими особами, які вчинили винні та протиправні діяння, які є караними відповідно до КУпАП. Кожна з названих груп суб'єктів поділяеться на загальні і спеціальні.

В антимонопольній сфрері спеціальний суб'єкт адміністративної відповідальності представлений посадовими особами органів влади, підприемцями, які здійснюють діяльність без створення юридичної особи і несуть відповідальність як посадові особи. У сфрері захисту конкуренції в якості суб'єкта адміністративної відповідальності можуть виступати громадяни, посадові особи.

Застосовувати заходи адміністративної відповідальності у сфері захисту конкуренції, в залежності від різновиду даного правопорушення і застосовування процесуальних правил, може суд, антимонопольний орган.

Об'єктивна сторона адміністративного правопорушення містить такі елементи, як протиправне діяння (у формі дії або бездіяльності), суспільно шкідливі наслідки та причинно-наслідковий зв'язок між ними. Стосовно сфрери захисту конкуренції необхідно відзначити наступні моменти.

Перераховані вище адміністративні правопорушення у сорері захисту конкуренції відбуваються у фрормі дії (бездіяльності) і тягнуть суспільно шкідливі наслідки по відношенню до трьохелементного суб'єкту в особі: Україна, яка, гарантуе підтримку конкуренції та свободу економічної діяльності; національних та іноземних суб'єктів господарювання; споживачів.

Шкода державі (законним економічним відносинам) завжди заподіюеться безпосередньо, у той час як шкода господарюючим суб'єктам і споживачам може бути прямою та непрямою.

Недобросовісна конкуренція шляхом некоректного порівняння приносить пряму шкоду діловій репутащії господарюючого суб'єкта, завдаючи непрямої шкоди споживачам, так як створює плутанину та формує неправильне уявлення про учасників господарського обороту. Слід відзначити, що зі структури об'єктивної сторони випливає така ознака, як суспільна шкідливість адміністративного правопорушення. Дане питання $€$ дискусійним в адміністративно-правовій науці.

Існує думка, що характерною ознакою адміністративного правопорушення є суспільна небезпека, та відмежувати його від злочину можливо тільки через аналіз ступеня суспільної небезпеки. Застосування ознаки суспільної небезпеки до всіх правопорушень ставить питання про межі цього поняття, яке охоплюе великий перелік діянь. Крім ступеня загрози суспільним відносинам, характерною ознакою може виступати і суб'єктний склад.

Вирішальним аргументом на підтримку позиції про обгрунтованість виділення ознаки суспільної шкідливості є норми статей 10, 11, 34 КУпАП, які, крім іншого, вказують на суспільно шкідливі наслідки адміністративних правопорушень, що можна розглядати як законодавче підгрунтя для виділення ознаки суспільної шкідливості адміністративних правопорушень.

Суб'єктивна сторона адміністративного правопорушення у сорері захисту конкуренції знаходить вираз в сукупності ознак, що відбивають свідомо-вольовий зміст скоєного.

КУПАП встановлюе дві форми провини у формі умислу і необережності. Аналіз складів адміністративних правопорушень в сфері захисту конкуренції показуе, що об'єктивна сторона кожного з відповідних діянь представляе активну, усвідомлену дію.

Н. П. Бортник і С. С. Ссімов зазначають, що вина - принципова підстава відповідальності, яка займає центральне місце в системі ознак, необхідних для кваліфрікації правопорушення [5, с. 149].

Психологічний момент відносини правопорушника до скоєного діяння у даному випадку залишається без уваги, тому для адміністративного правопорушення, вчиненого фрізичною особою, характерний склад, який має чотири елементи.

Серед підстав адміністративної відповідальності у сфрері захисту конкуренції необхідно виділити процесуальну підставу, під якою слід розуміти протокол про адміністративне правопорушення. Варто зазначити, що питання щодо того, що саме вважати процесуальною підставою адміністративної відповідальності не однозначний.

Так, H.M. Конін процесуальною підставою пропонуе вважати постанову про призначення адміністративного покарання, аргументуючи це тим, що залучення до адміністративної відповідальності не завжди вимагає складання адміністративного протоколу (наприклад, в разі призначення покарання у формі попередження або адміністративного штрафру на місці вчинення правопорушення; при виявленні правопорушення засобами відео фріксації).

3 огляду на специфіку сорери захисту конкуренції, процесуальна підстава може мати різну форому.

Умови відповідальності - це сукупність обставин, закріплених в КУпАП, що враховуе посадова особа (орган), що веде провадження у справі, щодо конкретної особи. Умови адміністративної відповідальності складають наступні обставини: наявність події та складу адміністративного правопорушення; винність особи, яка притягається до адміністративної відповідальності; вік, після досягнення якого настає адміністративна відповідальність; відсутність обставин крайньої необхідності; осудність правопорушника; однократність адміністративної відповідальності; дію строків давності притягнення до адміністративної відповідальності. У copepi захисту конкуренції строк давності становить п'ять років у випадку провадження, що здійснюеться антимонопольним органом [6]. 
Всі названі обставини в обов'язковому порядку повинні враховуватися при розгляді справ у сорері захисту конкуренції. Існуе додаткова умова у вигляді наявності конкурентних відносин між господарюючими суб'єктами, якщо мова йде про таке правопорушення, як недобросовісна конкуренщія.

Адміністративне покарання. Відповідно до КУПАП адміністративне покарання є встановленою державою мірою відповідальності за вчинення адміністративного правопорушення, застосовуеться $з$ метою попередження вчинення нових правопорушень правопорушником і іншими особами.

У copepi захисту конкуренції адміністративне покарання представлено такими санкціями, як адміністративний штрафр. Адміністративний штрафр - це обов'язкове грошове стягнення, яке виражається в гривнях, воно міститься у всіх складах адміністративних правопорушень у сореpi захисту конкуренції. 3 огляду на специфіку конкурентних відносин, адміністративний штрафо $\epsilon$ найбільш ефрективним заходом адміністративно-правового впливу на правопорушників, володіючи дією припинення та превентивною дією відносно господарюючих суб'єктів, що прагнуть до отримання додаткового прибутку (наприклад, шляхом недобросовісної конкуренції).

Розмір адміністративного штрафру може бути фіксованим або обчислюеться в залежності від розміру суми виручки правопорушника від реалізації товару (роботи, послуги), на ринку де вчинено адміністративне правопорушення.

Об'єктивна складність окремих складів у сорері захисту конкуренції породжуе громіздкий опис окремих санкцій, що тягне труднощі у застосуванні права. Належність сфери захисту конкуренції до галузі економічної діяльності разом 3 високою ефрективністю зумовлюють поширеність адміністративного штрафу серед заходів адміністративного покарання.

Провадження у справах про адміністративні правопорушення. Питання провадження у справах про порушення антимонопольного законодавства врегульовані Розділом IV КУпАП.

Даний вид провадження це діяльність спещіальних суб'єктів публічної влади, що здійснюється у процесуальній формі спрямована на виявлення фрактичних обставин вчиненого адміністративного правопорушення, встановлення особи правопорушника, його провини та вирішення питання про можливість притягнення до адміністративної відповідальності.

У copepi захисту конкуренції специфріка даного провадження знаходить вираз у додатковому приводі до порушення справи про адміністративне правопорушення у вигляді прийняття Постійною адміністративною колегією або адміністративною колегією територіального антимонопольного ор- гану відповідного рішення, що встановлюе порушення антимонопольного законодавства.

Дане правило використовуеться по відношенню до складів адміністративних правопорушень, установлених статтями 166-1 - 166-4 КУпАП. Відповідно до положень Закону «Про захист економічної конкуренції», якщо в ході розгляду справи про порушення антимонопольного законодавства антимонопольний орган виявить обставини, що свідчать про наявність адміністративного правопорушення, то порушуе справу про адміністративне правопорушення в порядку, встановленому законодавством України про адміністративні правопорушення.

Залишається відкритим питання про те, що ця норма відсилає до положень Глави 18 КУпАП (регулює порядок провадження у справах про адміністративне правопорушення взагалі) або саме до частини 1 статті 246 КУпАП. Частково відповідь дають Правила розгляду заяв і справ про порушення законодавства про захист економічної конкуренції (Правила розгляду справ), які встановлюють повноваження антимонопольного органу щодо порушення справи про адміністративне правопорушення [7]. Це показуе хибність звуження числа приводів для порушення справи про адміністративне правопорушення антимонопольним органом, яке визначено в чинному КУпАП, що вимагає коригування чинного законодавства в зазначеній частині.

Висновки. Адміністративну відповідальність за правопорушення у сфрері захисту конкуренції пропонуеться розуміти як вид адміністративної відповідальності, застосовуваний судовими або несудовими органами при встановленні складу адміністративного правопорушення в фрормі монополістичної діяльності або недобросовісної конкуренції і безпосередньо або побічно заподіює шкоду правам і законним інтересам конкурента, споживачів і конкуренції в цілому, що знаходить вираз у застосуванні адміністративних покарань у вигляді адміністративного штрафру. У структуру адміністративної відповідальності входять елементи: її підстава (фактична і юридична); перелік правових умов залучення до адміністративної відповідальності та умов, що її виключають; суб'єкт адміністративної відповідальності; передбачені законодавством санкщії. Специфікою розгляду справ про правопорушення в даній сфрері є окреме провадження - провадження у справах про порушення антимонопольного законодавства, результатом якого може стати порушення справи про адміністративне правопорушення. Нормативне врегулювання такого результату вимагає коригування в частині розширення наявного в чинному законодавстві переліку приводів до порушення справ про адміністративні правопорушення антимонопольним органом.

\section{Список літератури:}

1. Ковалів М.В., Ссімов С.С., Гулак Л.С., Остапенко О.І. та ін. Адміністративне право України (загальна частина) : навчальний посібник. Львів : НУ «Львівська політехніка», 2019. 504 с.

2. Кодекс України про адміністративні правопорушення : Закон України від 07.12.1984 p. № 8073-X. URL: https://zakon.rada.gov.ua/laws/show/80731-10/conv\#n1757

3. Про захист економічної конкуренщії : Закон України від 11.01.2001 p. № 2210-III. URL: https://zakon.rada.gov.ua/ laws/card/2210-14

4. Про захист прав споживачів : Закон України від 12.05.1991 p. № 1023-XII. URL: https://zakon.rada.gov.ua/ laws/card/1023-12 
5. Бортник Н., Ссімов С. Адміністративне правопорушення в бюджетній сфері як фрактична підстава адміністративної відповідальності. Вісник Національного університету "Львівська політехніка». Серія: Юридичні науки. 2020. Том 7. № 2(26). С. 146-153.

6. Щодо проблем через відсутність інформації стосовно провадження органами Антимонопольного комітету України справ про адміністративні правопорушення : Лист Антимонопольного комітету України від 13.11.2013 p. № 300-29/03-11118. URL: https://zakon.rada.gov.ua/rada/show/v1118226-13\#Text

7. Про затвердження Тимчасових правил розгляду справ про порушення антимонопольного законодавства України : Розпорядження Антимонопольного комітету України від 19.04.1994 p. № 5. URL https://zakon.rada.gov.ua/ laws/show/z0090-94\#Text

\section{References:}

1. Kovaliv M.V., Yesimov S.S., Hulak L.S., Ostapenko O.I. ta in. (2019) Administratyvne pravo Ukrayiny (zahalna chastyna): navchalnyy posibnyk. Lviv: NU «Lvivska politekhnika», $504 \mathrm{p}$.

2. Kodeks Ukrayiny pro administratyvni pravoporushennya: Zakon Ukrayiny vid 07.12.1984 r. № 8073-X. URL: https://zakon.rada.gov.ua/laws/show/80731-10/conv\#n1757

3. Pro zakhyst ekonomichnoyi konkurentsiyi: Zakon Ukrayiny vid 11.01.2001 r. № 2210 -III. URL: https://zakon.rada.gov.ua/laws/card/2210-14

4. Pro zakhyst prav spozhyvachiv: Zakon Ukrayiny vid 12.05.1991 r. № 1023-XII. URL: https://zakon.rada.gov.ua/ laws/card/1023-12

5. Bortnyk N., Yesimov S. (2020) Administratyvne pravoporushennya v byudzhetniy sferi yak faktychna pidstava administratyvnoyi vidpovidalnosti. Visnyk Natsionalnoho universytetu "Lvivska politekhnika». Seriya: Yurydychni nauky, tom 7, no. 2(26), pp. 146-153.

6. Shchodo problem cherez vidsutnist informatsiyi stosovno provadzhennya orhanamy Antymonopolnoho komitetu Ukrayiny sprav pro administratyvni pravoporushennya: Lyst Antymonopolnoho komitetu Ukrayiny vid 13.11.2013 r. № 300-29/03-11118. URL: https://zakon.rada.gov.ua/rada/show/v1118226-13\#Text

7. Pro zatverdzhennya Tymchasovykh pravyl roz hlyadu sprav pro porushennya antymonopolnoho zakonodavstva Ukrayiny: Rozporyadzhennya Antymonopolnoho komitetu Ukrayiny vid 19.04.1994 r. № 5 . URL: https://zakon.rada.gov.ua/laws/show/z0090-94\#Text 